\title{
Mortar mixes with oxblood: historical background, model sample recipes and properties
}

\author{
Kun Zhang ${ }^{1}$, Laura Rampazzi ${ }^{2}$, Maria Pia Riccardi ${ }^{3}$, Antonio Sansonetti ${ }^{4}$, and Alberto Grimoldi ${ }^{1}$ \\ ${ }^{1}$ Dep. DASTU, Polytechnic University of Milan, 20133 Milan, Italy \\ ${ }^{2}$ Dep. DISAT, University of Insubria, 22100 Como, Italy \\ ${ }^{3}$ Dep. Earth and Environmental Sciences, University of Pavia, 27100 Pavia, Italy \\ ${ }^{4}$ ICVBC, CNR National Research Council, 20125 Milan, Italy
}

Correspondence: Laura Rampazzi (laura.rampazzi@uninsubria.it)

Received: 18 May 2018 - Revised: 12 July 2018 - Accepted: 13 July 2018 - Published: 20 July 2018

\begin{abstract}
In this survey we present studies on mortar mixes added with oxblood, which was a commonly found local waste material, with a wide application and long history of use; a precise recipe of lime-pozzolan mortar with blood addition from a 19th-century Italian manual was chosen, and model samples were prepared accordingly, with the aim of better understanding the chemical, mineralogical and physical characteristics of such compositions, starting with a blank reference specimen. The specimens were analysed by means of scanning electron microscopy, infrared spectroscopy, thermal analysis and X-ray diffraction, and the results suggested that amorphous calcium carbonate could be formed in the specimens with oxblood addition. These preliminary results allow a better understanding of historical building practices, measuring effects induced by organic additives on mortar microstructure, as well as an evaluation of new performances obtained in mortar mixes. Moreover, this paper intends to propose a full multi-discipline approach to bridge the history of architecture and building materials to conservation science.
\end{abstract}

\section{Introduction}

In the past, many organic additives - especially proteinaceous and polysaccharide compounds - were added to mortars to improve their performances (Sickels-Taves and Allsopp, 2005). Oxblood was one of the most common protein materials added. Apart from improving mortar properties, its use in architecture could also be considered as a means of slaughterhouse waste disposal to avoid environ- mental contamination, especially in big cities. The aims of this research are to approach the subject of blood addition in mortars through a historic perspective and, more specifically, to understand historic knowledge of mortars with blood addition through preparation of model samples based on historic recipes, to verify, for example, credibility as well as feasibility of the chosen recipe, and to have a preliminary understanding of possible modifications in mortar microstructure, which could be induced by the blood addition.

\section{Historic recipes on blood additive in mortars}

The use of animal blood in mortars was mentioned in many ancient texts from both Europe and Asia, e.g. in Palladius (4th-5th century AD) and Plat and Boate (1653). With the emergence and development of modern chemistry in the 18th and 19th century, historic accounts documented recipes with more precise compositions and more specific applications of such mortars. According to these recipes, they could be used as mastics for ceramic, vitreous and metal items (Croker et al., 1765; Tilloch, 1803), but moreover blood addition was also used in mortar mixes to produce plaster. For instance, a series of lime-pozzolan mortars added with oxblood gave a waterproofing quality, which was recorded in French and Italian treatises (Encyclopédie méthodique, 1791; Pegoretti, 1843; Brey, 1844; Corso di costruzioni civili e militari di Alberto Gabba, 1870). According to some English sources, oxblood beaten together with lime produces great flooring and plastering material (Aikin and Aikin, 1807; Breymann et al., 1885). Similarly, oxblood and clay tempered together could make a strong binding material for 
Table 1. Composition, apparent density, and particle size distribution of raw materials.

\begin{tabular}{|c|c|c|c|c|c|c|c|c|}
\hline & & Quicklime & $\begin{array}{r}\text { Hydrated } \\
\text { lime }\end{array}$ & & Pozzolana & $\begin{array}{r}\text { Opus } \\
\text { signinum }\end{array}$ & & $\begin{array}{r}\text { Iron } \\
\text { powder }\end{array}$ \\
\hline Composition (\%) & $\begin{array}{l}\mathrm{CaO}+\mathrm{MgO} \\
\mathrm{MgO} \\
\mathrm{CO}_{2} \\
\mathrm{SO}_{3}\end{array}$ & $\begin{array}{l}\geq 90 \\
\leq 5 \\
\leq 4 \\
\leq 2\end{array}$ & $\begin{array}{l}\geq 90 \\
\leq 5 \\
\leq 4 \\
\leq 2\end{array}$ & $\begin{array}{l}\mathrm{SiO}_{2} \\
\mathrm{Al}_{2} \mathrm{O}_{3} \\
\mathrm{Fe}_{2} \mathrm{O}_{3} \\
\mathrm{CaO} \\
\mathrm{MgO} \\
\mathrm{SO}_{3} \\
\mathrm{Na}_{2} \mathrm{O} \\
\mathrm{K}_{2} \mathrm{O} \\
\text { Reactive } \\
\text { silica as } \mathrm{SiO}_{2}\end{array}$ & $\begin{array}{r}48.5 \\
17.5 \\
8.1 \\
10.9 \\
2.8 \\
0.2 \\
1.0 \\
5.5 \\
38.6\end{array}$ & $\begin{array}{r}49.8 \\
15.5 \\
7.0 \\
9.9 \\
3.8 \\
- \\
1.3 \\
2.6 \\
32.2\end{array}$ & $\begin{array}{l}\mathrm{Fe} \\
\mathrm{C} \\
\mathrm{O}\end{array}$ & $\begin{array}{r}>99 \\
0.05 \\
0.6\end{array}$ \\
\hline $\begin{array}{l}\text { Apparent density } \\
\left(\mathrm{kg} \mathrm{m}^{-3}\right)\end{array}$ & & 850 & 400 & & 900 & 880 & & 4000 \\
\hline $\begin{array}{l}\text { Particle size } \\
\text { distribution } \\
\text { (mass \% passing } \\
\text { the sieve) }\end{array}$ & $\begin{array}{l}0.2 \mathrm{~mm} \\
0.09 \mathrm{~mm}\end{array}$ & $\begin{array}{r}- \\
100\end{array}$ & $\begin{array}{l}\geq 98 \\
\geq 93\end{array}$ & $\begin{array}{l}0.063 \mathrm{~mm} \\
0.05 \mathrm{~mm}\end{array}$ & $\begin{array}{l}\geq 90 \\
\geq 85\end{array}$ & $\begin{array}{l}\geq 90 \\
\geq 85\end{array}$ & $\begin{array}{l}0.16 \mathrm{~mm} \\
0.1 \mathrm{~mm} \\
0.063 \mathrm{~mm}\end{array}$ & $\begin{array}{l}\geq 99.8 \\
\geq 79.6 \\
\geq 69\end{array}$ \\
\hline
\end{tabular}

floors and walls (Plat and Boate, 1653; Neve, 1726; Chambers, 1728). In China, pig blood together with tung oil added to lime and brick dust mixtures has been used for applying plaster on wooden board substrate since the later part of Qing dynasty (1644-1912). When blood is added to mortars, the mortar is often described as quick-setting (Brey, 1844; Purgotti, 1857), water-repellent (Good, 1813; Ascolese, 1832), adhesive (Plat and Boate, 1653; Jones, 1827), fireproof (Turriano, 16th century; Brannt and Wahl, 1887), hard (Tilloch, 1803), and frost-resistant (Polini, 1850), etc.

To choose the recipe to be further studied experimentally, some requirements needed to be fulfilled: the mortar should be lime-based; blood should be the only organic additive in the mortar; the mortar should be used for construction purposes, with specific mortar function given; the ingredient amounts in the recipe should be given as precisely as possible. The final choice of the historic recipe used for samples preparation is quoted from a 19th-century Italian manual (Pegoretti, 1843), which is reported as a "common mastic" for masonry plaster and stucco, or for pavement connections. It is described that the materials needed to compose $1 \mathrm{~kg}$ of such mastic are the following: " $0.12 \mathrm{~kg}$ of quicklime in powder; $0.25 \mathrm{~kg}$ of oxblood, in which the lime is slaked; $0.70 \mathrm{~kg}$ or $0.00054 \mathrm{~m}^{3}$ of pozzolana; $0.0275 \mathrm{~kg}$ of iron filings". This recipe not only accounts for the precise amount of each ingredient but also recalls other similar historic recipes from 18th- to 20th-century literature. To be specific, the recipe that we have chosen, along with a series of recipes with similar compositions and similar mortar functions, could have all been derived from a single recipe in Encyclopédie méthodique (1791). This presumably Frenchorigin mix was cited in many later publications (e.g. Pe- goretti, 1843; Brey, 1844; Corso di costruzioni civili e militari di Alberto Gabba, 1870). In addition, the credibility and practicality of the chosen recipe can be established by the literature source-Manuale pratico per l'estimazione dei lavori architettonici, stradali, idraulici e di fortificazione - which is a work that bears a lot of diligence from the Italian engineer Giovanni Pegoretti, and it is written with information as detailed as possible to guide builders and engineers.

\section{Model sample preparation}

\subsection{Raw materials}

The mortar mix was comprised of the following materials: micronized quicklime (La Banca Della Calce, CL 90Q), hydrated lime (Gras Calce, CL 90-S), micronized natural Roman pozzolana (Opificio Bio Aedilitia, in red colour), micronized opus signinum (Opificio Bio Aedilitia, in red colour), iron powder (Metall Pulver 24), and fresh oxblood obtained from a suburban slaughterhouse in Milan (Italy). The composition and some significant properties of the raw materials according to their product technical sheets are shown in Table 1.

\subsection{Model samples}

Four mortar mixes were prepared together; their compositions are listed in Table 2. Mortar mix A was prepared according to the chosen recipe as described in Sect. 2; three more mortar mixes $(\mathrm{B}, \mathrm{C}, \mathrm{D})$ were prepared in order to verify the effect of specific ingredients in the recipe. In mortar mix $\mathrm{D}$, opus signinum is added instead of pozzolana, with the 
Table 2. Compositions of the mortar mixes in weight (g).

\begin{tabular}{lcccccccr}
\hline Specimen & Quicklime & $\begin{array}{c}\text { Hydrated } \\
\text { lime }\end{array}$ & Oxblood & Water & Pozzolana & $\begin{array}{c}\text { Opus } \\
\text { signinum }\end{array}$ & $\begin{array}{c}\text { Iron } \\
\text { powder }\end{array}$ & $\begin{array}{r}\text { Additional } \\
\text { water }\end{array}$ \\
\hline A & 10 & - & 20.8 & - & 58.3 & - & 2.3 & 4.5 \\
B & 10 & - & - & 20.8 & 58.3 & - & 2.3 & 3 \\
C & - & $13.2^{*}$ & 20.8 & - & 58.3 & - & 2.3 & 7 \\
D & 10 & - & 20.8 & - & - & 58.3 & 2.3 & 7 \\
\hline
\end{tabular}

* Theoretical amount of hydrated lime produced by slaking $10 \mathrm{~g}$ of quicklime.
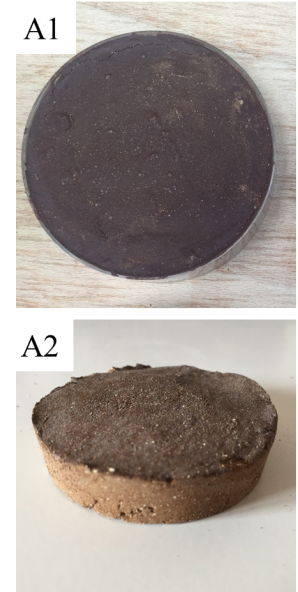

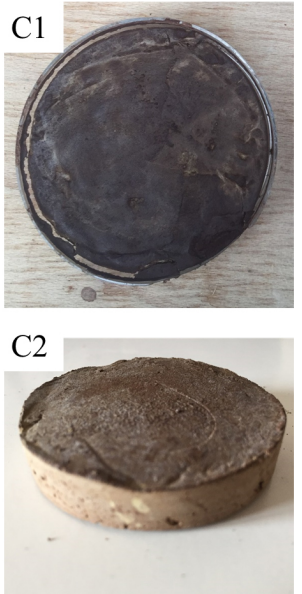
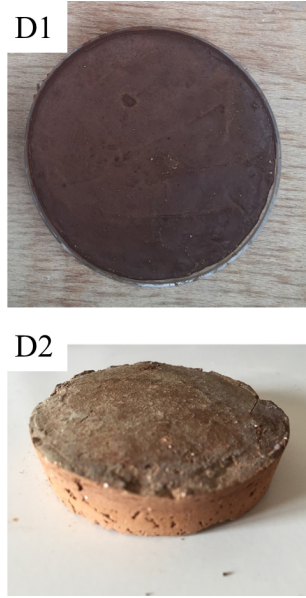

Figure 1. Appearance of prepared model samples.

intention of highlighting possible effects induced by different inorganic additives in lime-pozzolan mortars. Compositions of the pozzolana and opus signinum used in this paper are similar (Table 1), but pozzolana has slightly higher amounts of $\mathrm{Al}_{2} \mathrm{O}_{3}, \mathrm{Fe}_{2} \mathrm{O}_{3}, \mathrm{CaO}, \mathrm{SO}_{3}$, and $\mathrm{K}_{2} \mathrm{O}$ and lower amounts of $\mathrm{SiO}_{2}, \mathrm{MgO}$, and $\mathrm{Na}_{2} \mathrm{O}$. It should be noted that the reactive silica as $\mathrm{SiO}_{2}$ in pozzolana $(38.6 \%)$ is higher than in opus signinum ( $32.2 \%$ ), suggesting the higher pozzolanic reactivity of pozzolana. The amounts of the mortar ingredients were reduced according to the chosen recipe by proportion of weight, in order to cast the model samples in the plastic disc moulds with a volume of $25 \mathrm{~cm}^{3}$. The water amount in each mortar mix was determined after several tries in order to give each mortar mix its own appropriate consistency. The model samples were prepared by firstly homogeneously mixing the lime (quicklime/hydrated lime) and water (oxblood/water) together, then continuing to stir while adding the inorganic additives (pozzolana/opus signinum, iron powder) into the mixture until achieving a workable mortar paste. Each mixed mortar was then poured into a plastic disc mould and kept in laboratory conditions $\left(\sim 25^{\circ} \mathrm{C}, \sim 50 \% \mathrm{RH}\right)$ for the final curing.

The appearance of the prepared model samples is shown in Fig. 1. Upon visual observation, one obvious difference among the specimens is that a distinctive dark red colour can be noted on the top surface of specimens A, C, and D, which are with blood addition (A1, C1, D1). According to Grendi, (2004), in ancient times in Genoa (Italy), oxblood could be used as a colouring material for brick floors; a pierce of 19th-century Italian literature (Purgotti, 1857) mentioned that when blood serum was added in lime, the resulting mortar could have a yellowish colour. These clues might indicate that, when whole blood is added in lime mortars, it could serve the purpose of colouring or dyeing, especially when such mortars are used as plasters and stuccos. Another difference can be noted for the specimens with blood addition regarding the difference between their surface and the bulk (A2, C2, D2), which could indicate different chemical compositions between surface and bulk of these specimens; the possible segregation of proteins on the outer surface is also considered.

\subsection{Problems in sample preparation}

One of the problems encountered during sample preparation is that the apparent density values of the materials used in this research are different from those calculated according to the information given in Pegoretti (1843). For instance, the density of the quicklime lumps is given as $1050 \mathrm{~kg} \mathrm{~m}^{-3}$ in Pegoretti (1843), but the quicklime that was used in this study is in powder form, with an apparent density of $850 \mathrm{~kg} \mathrm{~m}^{-3}$ according to the product technical sheet. Similarly, the apparent 

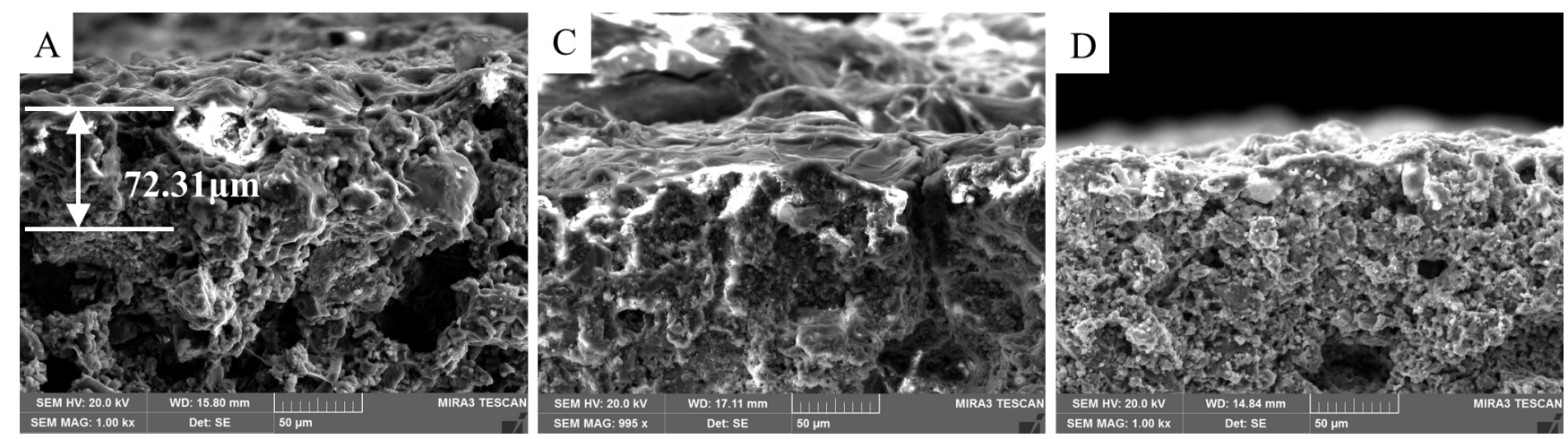

Figure 2. SEM images on the cross section of the top surface of specimen A, C, D.

density values of pozzolana and opus signinum mentioned on several occasions are around $1200-1300 \mathrm{~kg} \mathrm{~m}^{-3}$, and for metal slag dust the value is $2000 \mathrm{~kg} \mathrm{~m}^{-3}$; while the densities of the materials used in this study are 900 (pozzolana), 880 (opus signinum), and 4000 (iron powder) $\mathrm{kg} \mathrm{m}^{-3}$ (Table 1). The differences in apparent density values could induce differences in the executed mortar mixes. For example, when mortar mix A was prepared exactly according to the Pegoretti recipe, the resulting paste is very dry, so additional water had to be added so that the mortar could achieve its appropriate consistency (Table 2). One of the consequences of the general lower apparent density of the used materials could be the higher water demand of the mortar mix, which probably resulted from the larger specific surface of the materials.

Another interesting issue in reconstructing the ancient technique is that, under normal conditions, blood coagulates within only few minutes after it is taken from the animal, which makes it difficult to homogeneously mix blood with the other mortar ingredients. According to historic literature, the possible measures to prevent blood coagulation could be the following: (1) separation of the fibrins by "shaking" (Lancet, 1840; Brey, 1844) or "whipping" (Francis, 1845; Lehner, 1877) while collecting the blood, which is in modern era known as defibrination; (2) lower blood storing temperatures to delay or even interrupt coagulation (Davy, 1828; Olbrich et al., 1972); and (3) addition of chemicals such as salts $\left(\mathrm{NaCl}\right.$; Richardson, $1858 ; \mathrm{Na}_{2} \mathrm{SO}_{4}$; Hewson, 1771) into blood. However, the above-mentioned three measures to prevent blood coagulation are impossible to be realized in the present study for the following reasons: (1) it is impossible to execute defibrination while collecting the blood at the slaughterhouse; (2) the temperature for the blood to remain fluid (around $0^{\circ} \mathrm{C}$ ) is too low for the blood to slake quicklime, as required by the chosen recipe; (3) the addition of salts into blood might cause adverse effects on the final mortar properties. Eventually, we managed to add blood in mortar mixes in uncoagulated form by sifting out the fibrins through gauze after the blood was collected, as indicated also in Miklin-Kniefacz et al. (2016). After this process, the remaining blood, when kept in a closed glass jar, could remain fluid for at least $48 \mathrm{~h}$ without coagulation.

\section{Experiment}

SEM/EDS was performed using a Field Emission Gun Tescan Mira 3XMU-series FE-SEM equipped with an EDAX microanalytical system (accelerating voltage $20 \mathrm{kV}$, beam current $40 \mathrm{~mA}$, working distance $15.8 \mathrm{~mm}$ ). Attenuated total reflectance (ATR) spectra were recorded by Thermo Scientific Nicolet iS10 instrument equipped with a diamond crystal (wavenumber $4000-600 \mathrm{~cm}^{-1}$, resolution $4 \mathrm{~cm}^{-1}$, 32 scans). X-ray diffraction (XRD) was conducted using a Rigaku Miniflex 300 instrument $(30 \mathrm{kV}, 10 \mathrm{~mA}, \mathrm{Cu}-\mathrm{K} \alpha$ radiation $-\lambda=1.5418 \AA$ ), $5-85^{\circ}$ Theta/2-Theta, step scan $0.02^{\circ}$, scan speed $3^{\circ} \mathrm{min}^{-1}$ ). Thermogravimetry and differential scanning calorimetry (TG/DSC) was carried out with a NETZSCH STA 409 PC instrument (room temperature $1000^{\circ} \mathrm{C}$, pure $\mathrm{N}_{2}$ atmosphere, heating rate $10^{\circ} \mathrm{C} \mathrm{min}^{-1}$ ).

\section{Laboratory results and discussion}

As mentioned in Sect. 3.2, there is a colour difference between the top surface and the bulk of the specimens with blood addition (A, C, D). SEM images on the cross section of these specimens show THE presence of "film" covering their top surface (Fig. 2). This film seems to be thicker $(\sim 70 \mu \mathrm{m})$ in specimen $\mathrm{A}$ and appears to have gradually merged into the bulk; in specimen C and D the film is thinner, gathering on the very top of the specimens, with a thickness of around $10-20 \mu \mathrm{m}$.

According to Fig. 3, in specimen B, rhombohedral calcite particles can be clearly distinguished (B1); in specimen A, $\mathrm{C}$ and $\mathrm{D}$, the $\mathrm{CaCO}_{3}$ particles appear to be in less defined or A rounded shape (A1, C1, D1). Additionally, in specimens $\mathrm{A}, \mathrm{C}$ and $\mathrm{D}$ - taking specimen $\mathrm{C}$ as an example the $\mathrm{CaCO}_{3}$ particles appear to be connected with bridge-like 

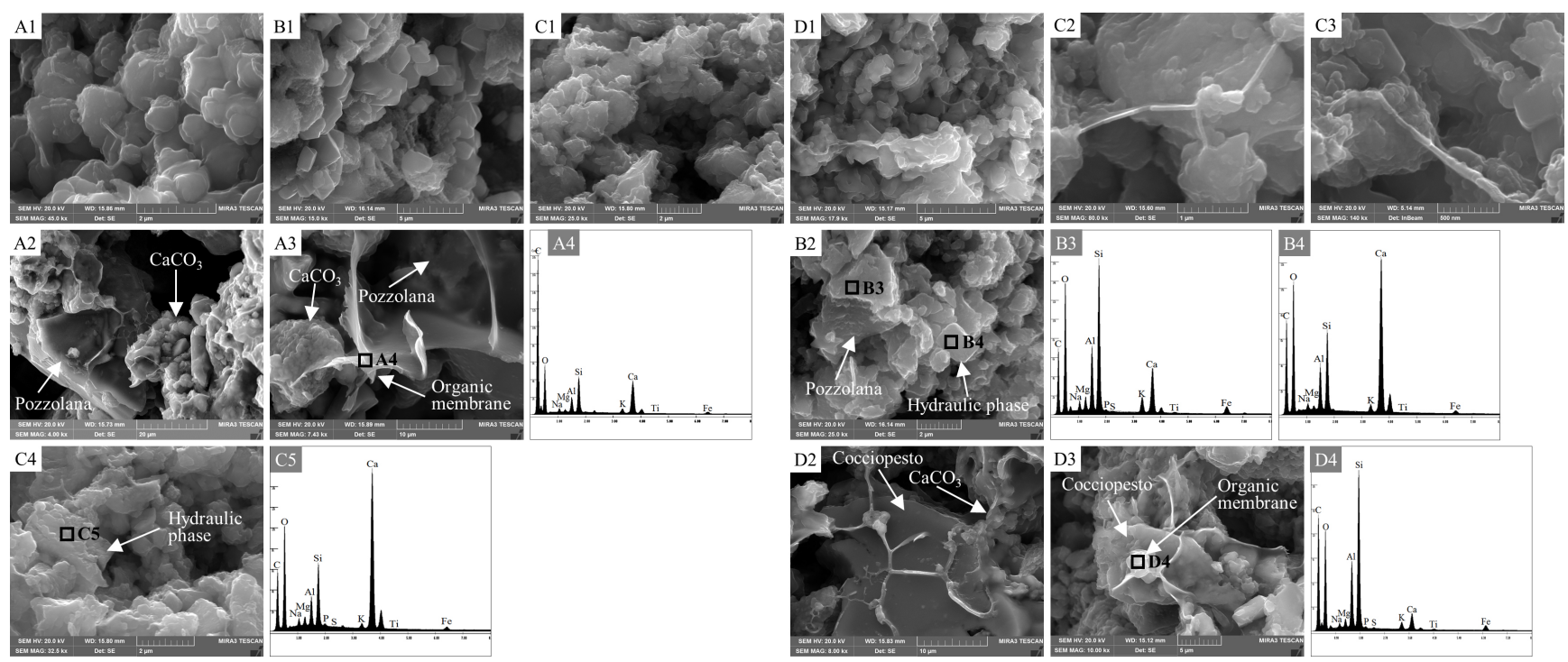

Figure 3. SEM images of $\mathrm{CaCO}_{3}$ particles (A1-C3), hydraulic phases and their respecting EDS spectra (A2-D4) in specimen A (quicklime+ oxblood+pozzolana+iron powder, B (quicklime + water+pozzolana+iron powder), $\mathrm{C}$ (hydrated lime+oxblood+pozzolana+iron powder), $\mathrm{D}$ (quicklime + oxblood + opussigninum + iron powder).

structures $(\mathrm{C} 2, \mathrm{C} 3)$, which could be due to the oxblood addition to them. Figure 3 shows some more differences between the hydraulic phases in specimens $\mathrm{A}$ and $\mathrm{D}$ and specimens $\mathrm{B}$ and C. In specimen A and D (A2, D2), no obvious signs of hydraulic phases can be observed; instead, the $\mathrm{CaCO}_{3}$ particles and pozzolana are covered and connected by a network of membranes (A3, D3). EDS spectra of these membranes (A4, D4) show higher contents of carbon, indicating their organic origin (i.e. the oxblood). Moreover, considering the compositions of the specimens (Table 2), the organic membranes could be specifically resulted from the quicklime and the oxblood, an issue which needs further study. In specimen B and C, however, hydraulic phases in cubic shape were observed in both specimens (B2, C4), which might be attributed to hydrogarnet $\left(\mathrm{C}_{3} \mathrm{AH}_{6}\right)$ (Madej et al., 2013).

In order to further investigate the nature of the $\mathrm{CaCO}_{3}$ formed in the specimens, analyses such as ATR, XRD and TG/DSC were performed. For specimens A, C and D, which contain oxblood, their ATR spectra show low intensity of the calcite $v 4$ band at $\sim 713 \mathrm{~cm}^{-1}$; XRD patterns show low intensity of the main calcite peak at $2 \theta \approx 29.5^{\circ}$; TG and DSC curves of specimens $\mathrm{A}, \mathrm{C}$ and $\mathrm{D}$ indicate relatively lower decomposition temperatures of $\mathrm{CaCO}_{3}$ than those of specimen B, which is without blood. All these results seem to support the fact that amorphous calcium carbonate could be formed in the specimens with oxblood addition, which is also suggested by the less-defined shape of $\mathrm{CaCO}_{3}$ particles in the SEM images (Fig. 3 - A1, C1, C2, C3, D1). The details of the analysis results will be elaborated on in future publications.

\section{Conclusion and future works}

In this study, model samples prepared according to a relatively precise historic recipe were investigated. During sample preparation, the feasibility of the ancient recipe was discussed, and a better understanding of historic knowledge on lime mortars with blood addition was achieved. Some characteristics of mortars with blood addition were noted, such as the distinctive dark red colour on the top surface, the presence of "film" covering the top surface, the presence of organic membranes, as well as the less-defined shape of the calcium carbonate, and they could serve as some first indications for the characterization of historic mortar samples with organic - or even blood - additives.

This study intends to emphasize the importance of understanding properties and characteristics of lab-prepared model samples taking into account the historical framework as a crucial point; the model samples were in fact set up on the basis of a careful survey into relevant ancient sources and literature. Such a framework is of great significance, since when trying to understand a traditional material (such as the "common mastic" presented in this study), historic investigations were often partly neglected. Even when fully completed, their significance was not framed in a scientific experimental project. A great deal of scientific data have been collected from a series of analyses (e.g. ATR, XRD, TG/DSC) performed on these model samples, and the results, which are organized under various topics, will be published in several future publications, referring to the historic framework setup in the present study. The challenge of the present work relies on a full multi-discipline approach to bridge the history of architecture and building materials to conservation science. 
Data availability. Data are available upon request by contacting the correspondence author.

Author contributions. AG and AS conceived and designed the study. KZ investigated the historic literatures, prepared the model samples, and wrote the paper. MPR performed the scanning electron microscopy. LR and AS revised the manuscript. All authors read and approved the manuscript.

Competing interests. The authors declare that they have no conflict of interest.

Special issue statement. This article is part of the special issue "European Geosciences Union General Assembly 2018, EGU Division Energy, Resources \& Environment (ERE)". It is a result of the EGU General Assembly 2018, Vienna, Austria, 8-13 April 2018.

Edited by: Michael Kühn

Reviewed by: Rosario García-Giménez and one anonymous referee

\section{References}

Aikin, A. and Aikin, C. R.: A Dictionary of Chemistry and Mineralogy, in: vol. 2, J. and A. Arch, London, 1807.

Ascolese, V. A.: Manuale economico, pratico, rurale, Tip. dell'Ateneo, Napoli, 1832.

Brannt, W. T. and Wahl, W. H.: The Techno-chemical Receipt Book, H. C. Baird \& Company, New York, 1887.

Brey, G.: Dizionario enciclopedico tecnologico-popolare, G. Chiusi, Milano, 1844.

Breymann, G. A., Scholtz, A., and Lang, H.: Trattato generale di costruzioni civili con cenni speciali intorno alle costruzioni grandiose di G. A. Breymann, F. Vallardi, Milano, 1885.

Chambers, E.: Cyclopaedia: or, An Universal Dictionary of Arts and Sciences, London, 1728.

Corso di costruzioni civili e militari di Alberto Gabba, Stamperia dell'unione tipografico-editrice, Torino, 1870.

Croker, T. H., Williams, T., and Clarke, S.: The Complete Dictionary of Arts and Sciences, Society of Gentlemen, London, 1765.

Davy, J.: The Edinburgh Medical and Surgical Journal, John Stark, Edinburgh, 1828.

Encyclopédie méthodique: v.8, Chez Panckoucke, Paris, 1791.
Francis, W.: The Chemical Gazette, in: vol. 3, Richard \& John E. Taylor, London, 1845.

Good, J. M.: Pantologia: A New Cyclopaedia, Kearsley, London, 1813.

Grendi, E.: In altri termini: etnografia e storia di una società di antico regime, edited by: Raggio, O. and Torre, A., Feltrinelli, Milano, 2004.

Hewson, W.: An Experimental Inquiry: Into the Properties of the Blood, T. Cadell, London, 1771.

Jones, T. P.: The Franklin Journal and American Mechanics' Magazine, Franklin Institute, Philadelphia, 1827.

Lancet: J. Onwhyn, London, 1840.

Lehner, S.: Die Kitte und Klebemittel, A. Hartleben's Verlag, Vienna, 1877.

Madej, D., Szczerba, J., Nocuń-Wczelik, W., Gajerski, R., and Hodur, K.: Studies on thermal dehydration of the hydrated $\mathrm{Ca}_{7} \mathrm{ZrAl}_{6} \mathrm{O}_{18}$ at different water-solid ratios cured at $60^{\circ} \mathrm{C}$, Thermochim. Acta, 569, 55-60, 2013.

Miklin-Kniefacz, S., Pitthard, V., Parson, W., Berger, C., Stanek, S., Griesser, M., and Kučková, Š. H.: Searching for blood in Chinese lacquerware: zhū xiě huī, Stud. Conserv., 61, 45-51, 2016.

Neve, R.: The City and Country Purchaser and Builder's Dictionary, A. M. Kelley, London, 1726.

Olbrich, S., Muhrer, M., Cooper, R., and Martz, F.: Effect of temperature and ration on blood clotting time of heat-tolerant and cold-tolerant cattle, Comparat. Biochem. Physiol. A, 41, 267280, 1972.

Palladius, R. T. A.: Opus agriculturae, $4^{\text {th }}-5^{\text {th }}$ century A.D.

Pegoretti, G.: Manuale pratico per l'estimazione dei lavori architettonici, stradali, idraulici e fortificazione, Editore Librajo Angelo Monti, Milano, 1843.

Plat, H. and Boate, A.: The Jewel House of Art and Nature, Elizabeth Alsop, London, 1653.

Polini, V.: Memoria sul metodo di coprire i tetti colle ottaedriche (etc.), Wilmant, Lodi, 1850.

Purgotti, S.: Trattato elementare di chimica applicata specialmente alla medicina e alla agricoltura, Vincenzo Bertelli, Perugia, 1857.

Richardson, B. W.: The Cause of the Coagulation of the Blood, J. Churchill, London, 1858.

Sickels-Taves, L. B. and Allsopp, P. D.: Lime and its place in the 21st century: combining tradition, innovation, and science in building preservation, in: International Building Lime Symposium, March 2005, Orlando, Florida, 2005.

Tilloch, A.: The Philosophical Magazine, Taylor \& Francis, London, 1803.

Turriano, J.: Los veintiún libros de los ingenios y máquinas, $16^{\text {th }}$ century. 